\title{
Türkçe Hedef Tabanlı Duygu Analizi İçin Alt Görevlerin İncelenmesi - Hedef Terim, Hedef Kategori Ve Duygu Sinıfi Belirleme
}

\author{
Fatih Samet ÇETİN, Gülşen ERYİĞİT \\ Bilgisayar Mühendisliği, İstanbul Teknik Üniversitesi, İstanbul, Türkiye \\ cetinfatih@itu.edu.tr, gulsen.cebiroglu@itu.edu.tr \\ (Geliş/Received:04.07.2017; Kabul/Accepted:13.12.2017) \\ DOI: $10.17671 /$ gazibtd. 325865
}

\begin{abstract}
$\ddot{O}_{z} \boldsymbol{e}$ - - Geleneksel olarak doküman veya cümle seviyesinde yürütülen duygu analizi çalışmaları, hedef tabanlı duygu analizi çalışmalarının ortaya çıkması ile yeni bir seviyeye taşınmışıtır. Hedef tabanlı duygu analizi (Aspect based sentiment analysis) kısaca, bir metnin içinde yer alan farklı duyguların ilgili oldukları hedef varlıklar ile birlikte tespit edilmesi olarak tanımlanabilir. Güncel tanımlamalar, hedef tabanlı duygu analizini, üç temel alanla (hedef terim, hedef kategori ve duygu sınıfi) temsil edilen duygu tanımlama grupların belirlemeyi amaçlayan aşamalı bir görev olarak betimlemektedir. Bu makalede, Türkçe hedef tabanlı duygu analizi konusunda yapılan incelemeler sunulmaktadır. Yürütülen çalışmalar, ABSA 2016 yarışmasındaki görevler (1- Hedef kategori belirleme, 2- Hedef terim belirleme, 3- Hedef kategori ve hedef terimin aynı anda belirlenmesi ve 4- Duygu sınıfı belirleme) takip edilerek tasarlanmış ve yine burada sağlanan Türkçe restoran yorumları veri kümesi üzerinde değerlendirilmişlerdir. Hedef kategori, hedef terim ve ikisinin aynı anda belirlenmesi görevleri için, kelime vektörleri (word vectors) ve doğal dil işleme çıktıları (sözcük ve cümle analizi bilgileri) kullanan koşullu rastgele alanlara (CRF - conditional random fields) dayalı bir dizilim etiketleme algoritması tasarlanmış ve her üç görevi de tek aşamada çözebildiği gösterilmiştir. Elde edilen sonuçlar ile bu ilk üç görev için literatürdeki en yüksek başarımların elde edildiği görülmüştür: Hedef kategori belirlemede \%66,7 F1-skoru, hedef terim belirleme \%53,2 F1-skoru, hedef kategori ve hedef terimin ayn anda belirlenmesinde \%46,7 F1-skoru. Bunun yanı sira, duygu sinıfi belirleme için cümle analizi sonucunda hedef terime yakın kelimelerden özellik seçimine dayalı bir lineer sınıflandırma yöntemi sunulmuş ve literatürde sınırlı sistemler tarafından raporlanan en başarılı sonuç (\%76,1 F1-skoru) elde edilmiştir.
\end{abstract}

Anahtar Kelimeler — hedef tabanlı duygu analizi, Türkçe, doğal dil işleme

\section{Investigation of Aspect Based Turkish Sentiment Analysis Subtasks - Identification of Aspect Term, Aspect Category and Sentiment Polarity}

\begin{abstract}
Sentiment analysis studies conducted traditionally at document or sentence level have been moved to a new level with the emergence of aspect based sentiment analysis studies. Aspect-based sentiment analysis can be briefly defined as the detection of different opinions contained within a text together with the target entities to which they relate. Current definitions describe aspect based sentiment analysis as a gradual task aiming to identify opinion tuples represented by three main fields (target term, target category, sentiment class). This article presents our investigations on aspect based Turkish sentiment analysis. The work carried out in this article is designed by following ABSA 2016 competition tasks (1- Aspect category identification, 2- Aspect term identification, 3- Identification of aspect category and aspect term together and 4- sentiment category classification) and evaluated on the Turkish restaurant reviews dataset provided in the same event. For the first three tasks, a sequence labeling algorithm (based on conditional random fields (CRF)) which uses word vectors and natural language processing outputs (word and sentence analyses) is proposed and shown to solve these three tasks in one step. Experimental results show that the proposed system achieves the highest performances for these tasks: $66.7 \%$ F1-score for aspect category identification, 53.2\% F1-score for aspect term identification, 46.7\% F1score for both aspect category and aspect term at the same time. Additionally, a linear classification method based on feature selection from positionally and syntactically neighboring tokens is proposed for sentiment category classification task and shown to perform as the best constrained system reported in the literature with $76.1 \% \mathrm{~F} 1$-score.
\end{abstract}

Keywords - aspect based sentiment analysis, Turkish language, natural language processing 


\section{GIIRIŞ (INTRODUCTION)}

Günümüzde sosyal medya kullanımı ve Web 2.0'ın yaygınlaşması ile birlikte, internetteki içeriklerin büyük çoğunluğu sosyal medya kullanıcıları tarafından üretilir hale gelmiştir. Eski dünyadan farklı olarak, sadece seçkin bir zümre değil artık her zümreden insanın kendini ifade edebildiği ve milyonlarca insana ulaşabildiği bir ortama geçilmiştir. $\mathrm{Bu}$ nedenlerle, günümüzde bu içerikler geçmişe göre çok daha hızlı ve büyük miktarda üretilmektedir. Farklı kanallar yolu ile (video, ses, metin vb...) içerik üretilmesine rağmen, sosyal medyada yer alan içeriklerin büyük bölümü insanların doğal dillerinde ürettikleri yazılardan oluşmaktadır.

Hizla artan bu veriden faydalanabilmek adına, kullanıcıların aldıkları ürün ve hizmetler ile ilgili görüşlerinin toplanması ve incelenmesi ve bu incelemeler 1şı̆̆ında her kurum veya firmanın kendine ait dersler çıkarabilmesi önemli bir ihtiyaç olarak karşımıza çıkmaktadır. Bu görevleri başarıyla yerine getirebilmek için sosyal medyada yapılan yorumların olabildiğince hızlı ve detaylı şekilde analiz edilmesi gerekmektedir. Bu analiz işlemini insan gücü ile gerçekleştirmenin oldukça zor ve maliyetli olduğu açıktır. Günümüzde doğal dil işleme ve veri madenciliği teknolojilerindeki gelişmeler, sosyal medya içeriklerini bilgisayar kullanarak otomatik yollar ile işlemeyi mümkün hale getirmiştir. Son yıllarda yapılan araştırmalarda, bu konunun yoğun olarak işlendiği görülmektedir. Araştırmaların ve uygulamaların büyük bölümü, bir metnin içerisindeki baskın duygu sınıfını belirlemek üzerinedir. Bu işleme, genel duygu analizi veya literatürdeki adı ile doküman seviyesinde duygu analizi denilmektedir [1-3]. Bu çalışmalardaki genel varsayım bir dokümanın ait olduğu tek bir duygu sınıfı (ör: pozitif, negatif duygu) olduğu şeklindedir. Daha detaylı analiz için çeşitli çalışmalarda cümle seviyesinde duygu analizi incelemeleri yapılmıştır $[2,4]$. $\mathrm{Bu}$ çalışmalarda ise doküman yerine cümlelerdeki baskın duygunun tahmin edilmesi konu alınmıştır.

Literatürde, doküman veya cümle seviyesinde analizler neticesinde yapılan çıkarımların yetersiz olduğu zamanla ortaya çıkmıştır. Doğal dillerde yazılan içeriklerde bir cümlede veya dokümanda tek bir duygunun olduğunu kabul etmek geçersiz bir varsayım olarak karşımıza çıkmaktadır. $\mathrm{Bu}$ sebeple bir cümle içerisindeki farklı duygu sinıflarının tespit edilmesi ve gösteriminin yapılması ihtiyacı doğmuştur. Liu [2], kitabında bu durumu şu şekilde belirtmiştir: "Ne doküman seviyesinde ne de cümle seviyesindeki duygu analizi, insanların tam olarak neyi sevdiği veya sevmediği konusunda bir bilgi verememektedir. İşte bu bilgiyi çıkarabilmek için hedef tabanlı (aspect based) (eski adı ile özellik tabanlı) duygu analizi yapmak gerekmektedir". Bahse konu olan çalışmada hedef tabanlı duygu analizinin amacı sübjektif yargıları (opinion) metin içerisinden çıkarabilmektir. Sübjektif yargı, duygu sinıfi (olumlu, olumsuz) ve o duygunun ilgili olduğu bir hedef olarak tanımlanmaktadır. Örneğin, "Bu telefonun kamerası oldukça net çekim yaparken, pil ömrü konusunda hiç de başarılı değil" cümlesinde birden fazla görüş ve dolayısı ile birden fazla duygu sınıfı olduğu görülmektedir. Telefonun "kamera" özelliğine olumlu bir atıf varken, "pil ömrü" özelliğinden olumsuz şekilde bahsedilmektedir. Liu'nun bu tanımının ardından, hedef tabanlı duygu analizi üzerine en güncel tanımlama 2014 - 2016 yılları arasında artarda düzenlenen Semeval ${ }^{1}$ ABSA (Aspect Based Sentiment Analysis) [5-7] ortak çalışmalarında yapılmıştır. $\mathrm{Bu}$ çalışmalarda farklı alanlardan ve dillerden duygu analizi verileri katılımcılar ile paylaşlarak, belirli bir süre içerisinde geliştirilen sistemler aynı veri üzerinde yarıştırılmakta ve ortak şekilde değerlendirilmektedirler. ABSA 2016 yarışmasında 7 farklı alan ve 8 farklı dilde duygu analizi veri kümesi araştırmacılar ile paylaşılmıştır. Bu veri kümeleri arasında Türkçe veri kümeleri de yer almaktadır.

Bu makale kapsamında yürütülen çalışmalar, ABSA 2016 yarışmasındaki görevler (1- Hedef kategori belirleme, 2Hedef terim belirleme, 3- Hedef kategori ve hedef terimin aynı anda belirlenmesi ve 4- Duygu sınıfi belirleme) (ayrıntılı görev tanımları için bknz. Bölüm 3) takip edilerek tasarlanmış ve yine burada sağlanan Türkçe restoran yorumları veri kümesi üzerinde değerlendirilmişlerdir. Hedef kategori, hedef terim ve ikisinin aynı anda belirlenmesi görevleri için, kelime vektörleri (word vectors) ve doğal dil işleme çıktıları (sözcük ve cümle analizi bilgileri) kullanan koşullu rastgele alanlara (CRF conditional random fields) dayalı bir dizilim etiketleme algoritması tasarlanmış ve her üç görevi de tek aşamada çözebildiği gösterilmiştir. Elde edilen başarımlar ile bu ilk üç görev için literatürdeki en yüksek başarımların elde edildiği görülmüştür: Hedef kategori belirlemede \%66,7 F1-skoru, hedef terim belirleme \%53,2 F1-skoru, hedef kategori ve hedef terimin ayn 1 anda belirlenmesinde \%46,7 F1-skoru. Bunun yanı sıra, duygu sınıfi belirlemede lineer sınıflandırma tekniği ve hedef terime yakın kelimelerden özellik seçim yöntemi ile sınırlı sistemler tarafından raporlanan en başarılı sistemden daha başarılı (\%76,1 F1skoru) bir sistem ortaya konmuştur.

Bölüm 2'de Türkçe'nin duygu analizi açısından sahip olduğu zorluklar ve daha önceki araştırmalar ele alınmıştır. Bölüm 3'te problemin yapısal tanımı verilmiş ve Bölüm 4'te veri üzerinde yürütülen ön işlemler tanıtılmıştır. Önerilen sistem Bölüm 5'te sunulmaktadır. Bölüm 6 yürütülen deneysel çalışmaları, Bölüm 7 ise sonuç ve gelecek çalışmaları sunmaktadır.

\section{TÜRKÇE VE DUYGU ANALIZİNDE KARŞILAŞILAN ZORLUKLAR (TURKISH AND ITS CHALLENGES FOR SENTIMENT ANALYSIS)}

Doğal dil işlemede üzerine sıklıkla çalışılan dillerden yapısal olarak farklı olan dillerde duygu analizi, özellikle de hedef tabanlı duygu analizi alanında çalışmalar yapmak 
çok daha zordur. Türkçe bu tür dillere önemli bir örnek teşkil etmektedir. Bunun en büyük sebeplerinden biri Türkçe'nin sondan eklemeli ve zengin biçimbilimsel yapısıdır. Batılı dillerde birçok kelimeden oluşan bir cümle, Türkçede tek bir kelime ile ifade edilebilmektedir. (Örneğin "he/she can not bring" - "getiremez"). Diğer dillerde sentaktik ilişkileri belirleyen (ör: from, to $v b$.) sözcükler, Türkçe'de biçimbilimsel seviyede ortaya çıkmaktadırlar. Bu özellikleri sebebiyle veriye dayal (corpus based) tekniklerde veri seyrekliği problemi ortaya çıkmaktadır. $\mathrm{Bu}$ da aynı ifadenin temsil oranını düşürmekte, eğitim kümesinde yer almayan bazı sözcük görünüş biçimleri (word surface forms) için çıkarım yapılamamasına yol açmaktadır. Türkçe'nin diğer bir önemli özelliği olan öğelerin cümle içi serbest dizilimi, duygu analizi çalışmalarında zorluklara yol açmaktadır. İngilizce gibi dillerde kelimeler arası ilişkileri incelerken sıralama önem ifade ederken, Türkçede serbest dizilim yüzünden kelimeler arası ilişkileri bulmak güçleşmektedir. Hedef tabanlı duygu analizi problemi özelinde bir örnek vermek gerekirse, bir hedef terimin duygusunu bulabilmek için yalnızca dizilim esasına göre kelimeye komşu diğer kelimelerden faydalanmak yeterli gelmemektedir.

Web 2.0 içeriklerinin incelenmesinde karşımıza çıkan bir diğer önemli problem ise, bu mecrada kullanılan dilin düzgün yazma kurallarına uymayışıdır. Türkçe gibi biçimbilimsel olarak zengin dillerde, eklerin de etkisi ile sözcüklerdeki hata çeşitlilikleri ve sayıları artmakta $[8,9]$ ve duygu analizi zorlaşmaktadır. Metin normalleştirme çalışmaları günümüzde halen aktif araştırma konuları olup, henüz tam anlamıyla olgunlaşmamışlardır. Çalışmalar genelde hatalı sözcüğün tespiti ve öneri şeklinde iki aşamadan oluşmaktadır. Eryiğit ve Torunoğlu [9] metin normalizasyonu çalışmalarında bu mecrada karşımıza çıkan problemleri yedi farklı başlık altında toplamışlardır. En sık karşılaşılan hata türünün ASCII (Bilgi Değişimi İçin Amerikan Standart Kodlama Sistemi) kod kümesinde olmayan Türkçe karakterlerin kullanımında yaşandığ görülmektedir ${ }^{2}$. Kullanıcılar günümüzde özellikle mobil cihaz klavyelerinin kullanımı esnasında Türkçe'ye özgü karakterler (ç, ğ,ş,ü,ö,İ,1) yerine ASCII kod kümesindeki karşılıklarını kullanabilmektedir. Morfolojik zenginliği sebebiyle ortaya çıkan veri seyrekliği problemi bu kullanım sebebiyle daha da derinleşmektedir.

Türkçe duygu analizi üzerine daha önce çeşitli çalışmalar yapılmıştır. Doğal dil işlemenin katkılarının sunulduğu çalışmalarda $[10,11]$, doküman seviyesinde yapılan duygu analizinde morfolojik özelliklerin katkıları sunulmuştur. Yakın zamanlı diğer bir çalışmada [12] doküman seviyesinde, cümle seviyesinde ve kısmen hedef tabanlı duygu analizinde sözlük tabanlı yaklaşımların katkıları sunulmuştur. Çalışmada hedef tabanlı duygu analizinin yalnızca daha önceden elle belirlenen hedef terimler için geçen duyguların sınıflarının tespit edilmesi üzerine

\footnotetext{
2 Bozuk yazılan sözcüklerin tespitinde yapılan hataların metnin anlamını bozma riski olması nedeniyle bu makalede sadece bu türe yönelik normalleştirme çalışmaları yapılmıştır. (bknz. Bölüm 4)
}

sonuçları raporlanmıştır. Hedef terime dair duygu sınıfı belirlenirken, terimin bağlllık ağacında ${ }^{3}$ ilişkisi olan kelimelerin incelendiği sistemin, pozisyon olarak yakın olan kelimelerin incelendiği yöntemden daha başarılı olduğu vurgulanmıştır.

\section{HEDEF TABANLI DUYGU ANALIZİ GÖREV TANIMI (TASK DESCRIPTION OF ASPECT BASED SENTIMENT ANALYSIS)}

ABSA yarışmalarında, bir cümlenin içerisinde bulunan duygu atıflarının tamamı, duygu tanımlama grubu (sentiment tuple) adı verilen yapılar halinde işaretlenmiştir. Bir tanımlama grubu temel olarak 3 bilgi taşımaktadır. Şekil 1'de görüleceği gibi bu bilgiler; hedef terim (target), hedef kategori (category) ve duygu sinıfidır (polarity). Hedef terimin metin içerisindeki kesin yerini bildirebilmek için başlangıç indisi (from) ve bitiş indisi (to) işaretli olarak sunulmaktadir. Hedef terim (target) duygunun atıfta bulunduğu cümle içindeki terimdir. Bu terim cümle içinde geçen bir kelime veya kelime öbeği olabilmektedir. Örneğin Şekil 1'deki cümlede “fiyatlarının” ve "yemeklerinin" sözcükleri iki ayrı hedef terim olarak belirlenmiştir. Kategori, duygunun atıfta bulunduğu ve veri için önceden belirlenmiş olan kategorilerdir. Kategori, verinin temsil ettiği alan için belirlenen hedef varlık (entity) ve hedef özelliklerin (attribute) çarprazlanması ile oluşmaktadır. Bu çalışma kapsamında üzerine çalışılan alan restoran alanıdır. Bu alan için verilmiş olan hedef varlık ve hedef özellikler Tablo 1'de gösterilmektedir. Şekil 1'deki tanımlama grubunda bulunan son bilgi ise tanımlama grubundaki duygu sınıfidır. Duygu sınıfının alabileceği 3 değer vardır. Bunlar; pozitif, negatif ve nötr'dür. ABSA'da duygu tanımlama grubunun içerisindeki bilgileri otomatik çıkarabilecek sistemler tasarlanabilmesi için yarışma dört alt göreve bölünmüştür. $\mathrm{Bu}$ alt görevler aşağıda sunulmaktadır.

Alt görev 1. Cümlenin barındırdığ duygu tanımlama gruplarının, ait olduğu hedef kategorileri ile birlikte tespit edilmesi beklenmektedir. Test kümesinde yalnızca cümleler sunulmuş ve katılımcılar tarafından tasarlanacak olan sistemin, bu cümlelerde bulunan duygu tanımlama gruplarının doğru sayıda üretmesi ve içlerine sadece kategori bilgilerini doğru şekilde doldurması beklenmektedir. Bir cümlede aynı kategoriye ait birden fazla duygu tanımlama grubu olması ihtimali vardır. Bu duygu tanımlama grupları hedef terim ve veya duygu sinifı üzerinden farklılaşmaktadır. Bu görevin değerlendirilmesinde, bir cümlede birden fazla aynı kategoriyi içeren duygu tanımlama grubu olması halinde teke indirgenerek değerlendirme yapılmaktadır.

Alt görev 2. 1 numaralı alt görevde verilen test kümesinin aynısı bu görev için de kullanılmaktadır. Duygu tanımlama gruplarının üretilip, içerisindeki

3 Bağlılık ayrıştırması (dependency parsing) literatürde Türkçe'nin cümle analizi için sıklıkla kullanılan bir yaklaşımdır [13]. 
hedef terimlerin başlangiç ve bitiş indisleri ile birlikte tespit edilmesi beklenmektedir.

Alt görev 3. Önceki alt görevlerdeki gibi verilen cümleden duygu tanımlama gruplarının üretilmesi ve içlerinde hem kategori hem de terimin aynı anda doğru olarak tespit edilmesi beklenmektedir.

Alt görev 4. Diğer alt görevlerden farklı olarak, test verisi cümleler ile beraber doğru duygu tanımlama gruplarını (görevli işaretleyici uzman kişiler tarafindan önceden elle işaretlenmiş) barındırmaktadır. Duygu tanımlama gruplarındaki duygu sınıfi değerleri boş bırakılmıştır. Bu göreve sistemlerin, duygu sınıfi değerlerini tespit etmesi beklenmektedir.

Bu makalede, 2016 y1lındaki ortak görevde paylașılan verilerden Türkçe için sunulan Restoran veri kümesi kullanılmıştır. Sunulan veri kümesi, 1232 adet eğitim 183 adet test cümlesi barındırmaktadır. Eğitim kümesindeki cümlelerin 128 adeti, test cümlelerinin ise 20 adeti kapsam dışında yani duygu tanımlama grubu barındırmayan kayıtlardır.

Yukarıda anlatılmış olan alt görevlerin değerlendirilmesinde başvurular iki grupta ele alınmıştır. Sistemlerinin eğitimi sırasında sadece yarışma kapsamında paylaşılan veri kümelerini kullanan sistemler sınırlı (constraint), ABSA tarafından paylaşılan veri kümeleri haricinde dișarıdan veri kullanarak sonuçlar üreten sistemler ise serbest (unconstraint) sistemler olarak kategorize edilmişlerdir. Sınırlı sistemlerde, gövde bulucu (stemmer), sözcük çözümleyici ve bunlar gibi DDİ alt araçlarının kullanılmasına izin verilmiştir.

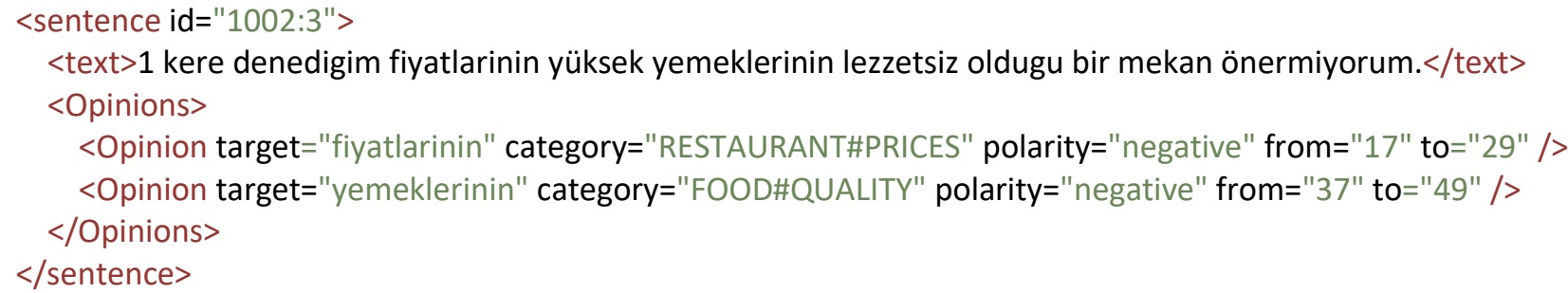

Şekil 1. Duygu tanımlama grupları ile işaretleme örneği (Sentiment tuple example of an annotated sentence)

Tablo 1. Hedef varlık ve hedef özellikler listesi (Lists of aspect entities and aspect attributes)

\begin{tabular}{|l|l|}
\hline Hedef Varlıklar & RESTAURANT, FOOD, \\
& DRINKS, AMBIENCE, \\
& SERVICE, LOCATION \\
\hline Hedef Özellikler & GENERAL, PRICES, \\
& QUALITY, \\
& STYLE_OPTIONS, \\
& MISCELLANEOUS \\
\hline
\end{tabular}

\section{VERİ ÖNISSLEME (DATA PREPROCESSING)}

Bu bölümde, çalışmada ele alınacak olan veri kümesinin, görevlerde uygulanacak yöntemlere hazır hale getirilmesi için gerçekleştirilecek olan ön işleme adımlarından bahsedilmektedir.

Duygu analizi aşamasına geçmeden önce Türkçe doğal dil işleme için çevrimiçi araçlar sunan ITU NLP Web servisi [14] kullanılarak veri üzerindeki dil bilimsel analizler otomatik yollarla elde edilmiştir. Kullanılan araçlar sırasıyla şöyledir:

- $\quad$ Kelime bölütleyici (tokenizer)

- Türkçe karakter düzeltici (deasciifier)

- Morfolojik çözümleyici (morphological analyzer)

- Morfolojik belirsizlik giderici (morphological disambiguator)

- Bağlılık ayrıştırıcısı (dependency parser)
Kelime bölütleyici, kendisine verilmiş olan bir metni kelimelerine bölerek, içerdiği kelimeleri döndüren bir araçtır. Türkçe karakter düzeltici, ASCII kod tablosunda bulunmayan Türkçe karakterlerin yerine ASCII tablosundaki karşılıklarının kullanıldığı bozuk yazımları düzeltmeye yarayan araçtır. Morfolojik çözümleyici, bir kelimenin olası biçimbilimsel çözümlemelerinin üretildiği aşamadır. Örneğin "kalem" kelimesinin bu araçtan alınan çözümleme sonuçları, "kalem+Noun+A3sg+Pnon+Nom", "kale+Noun+A3sg+P1sg+Nom" şeklinde iki adet çözümlemedir. Morfolojik belirsizlik giderme aracının görevi, bir önceki örnekteki gibi birden fazla çözümlemesi çıkan kelimelerden, bağlama en uygun olan çözümlemenin seçilmesidir. Bağlılık ayrıştırıcısının kullanım alanı ise, cümle içinde kelimeler arası bağların (özne, nesne vb.) ortaya çıkarılmasıdır. Ön işleme sonucunda elde edilen çıktıya bir örnek

Tablo 2'de sunulmaktadır. CONLL [15] formatındaki bu gösterimde sırasıyla şu özellikler verilmektedir:

1. ID: kelimenin cümle içindeki sırasını gösteren numerik değerdir.

2. Form: kelimenin cümle içinde geçtiği gibi gösterildiği, görünüm hali (surface form) olarak da adlandırılan halidir.

3. Lemma: Kelimenin gövdesi veya köküdür.

4. Evrensel Pos Etiketi (UPOSTag) : Genel kabul gören ve tüm diller için geçerli olan kelime tipi etiketidir. 
5. Dil özelinde POS Etiketi (XPOSTag) Dillerin ihtiyaç duyduğu kelime tipi etiketleri evrensel olanlardan farklılık gösterebilir. Bunlar bu bölümde gösterilmektedir.

6. Morfolojik özellikler: Morfolojik çözümlemeden gelen özellikler yani almış olduğu eklerin gösterildiği bölümdür.
7. Baş düğüm indisi (Head): Cümlenin bağlılık analizinden gelen bilgilerle, kelimenin bağlı olduğu baş düğümdeki kelimenin indisinin belirtildiği kolondur.

8. Bağlılık Tipi (DepRel) : Baş düğüm ile kelimenin arasındaki bağlantının tipinin gösterildiği kolondur.

Tablo 2. Cümlenin CONLL formatında gösterimi

(CONLL representation of a sentence)

\begin{tabular}{|r|l|l|l|l|l|l|l|}
\hline ID & FORM & LEMMA & UPOSTAG & XPOSTAG & FEATS & HEAD & DEPREL \\
\hline 1 & lokumun & lokum & Noun & Noun & A3sg|Pnon|Gen & 3 & POSSESSOR \\
\hline 2 & daha & daha & Adverb & Adverb & - & 3 & MODIFIER \\
\hline 3 & iyisini & iyi & Noun & NAdj & A3sg|P3sg|Acc & 4 & OBJECT \\
\hline 4 & yedim & ye & Verb & Verb & Pos|Past|A1sg & 7 & COORDINATION \\
\hline 5 & küşleme & küşle & Noun & Noun & A3sg|P1sg|Dat & 4 & MODIFIER \\
\hline 6 & - & güzel & Adverb & Adverb & - & 7 & DERIV \\
\hline 7 & güzeldi & - & Verb & Zero & Past|A3sg & 0 & PREDICATE \\
\hline 8 & - & - & Punc & Punc & - & 7 & PUNCTUATION \\
\hline
\end{tabular}

\section{SISTEM TASARIMI (SYSTEM DESCRIPTION)}

Bu bölümde, hedef tabanlı duygu analizi için takip edilen görevlere özel tasarlanan sistemlerimiz sunulmaktadır. Bölümde, öncelikle hedef terim çıkarma yaklaşımımız ardından hedef kategori tespiti ve her ikisinin eş zamanlı olarak çıkarılması için önerdiğimiz tasarımlar, son aşamada ise, ilgili duygu tanımlama grupları için duygu sınıfı tahminlenme yöntemimiz verilmektedir. Aşağıda, her alt göreve ilişkin bölümde seçilen yöntem ve kullanılan özellikler sunulmaktadır.

\subsection{Hedef Terim Çıkarımı (Opinion Target Extraction)}

Bu görevin amac1, 2. bölümde de anlatıldı̆̆ı gibi, cümle içerisinde duygu atıfinın yapılmış olduğu hedef terimin/terimlerin çıkarılabilmesidir. Çalışmamızda bu göreve bir dizilim etiketleme (sequence tagging) problemi olarak yaklaşılmıştır. Doğal dil işlemede dizilim etiketleme çözümleri sıklıkla metinlerdeki birimlere (kelimeler, karakterler, boşluklar vb.) verilmiş olan rollerin, o birimlerin ve komşularının taşımış oldukları çeşitli özelliklere göre otomatik tespit edilebilmesini amaçlayan çözümlerdir. Çalışmamızdaki dizilim etiketleme uyarlamasında, bir kelimenin hedef terim olup olmadı ğ sorusunun cevabı bulunmaya çalışılmıştır.

Hedef terim çıkarımı için yapmış olduğumuz tasarımda ilk adım veriyi dizilim etiketleyiciler için uygun olacak bir biçimde şekillendirmektir. Bölüm 46’te anlatıldığı üzere, veri kümesindeki cümleler, CONLL formatına dönüştürülmüştür. Bu biçimdeki verilerde cümleler,

Tablo 2'de sunulduğu üzere kelime kelime gösterilmektedir. Bu tabloda yer alan özellikler ve aşağıda tanıtılan ek özellikler kullanılarak, her kelimeye hedef terim olup olmadığını belirtir bir etiket atanmıştır.

Dizilim etiketleme için CRF [16] algoritması kullanılmıştır. Daha önceki çalışmalar bu tip problemler için CRF algoritmasının efektif bir yöntem olduğunu ortaya koymaktadır [17, 18]. Bu çalışmada, CRF Suite [19] kütüphanesinin Python gerçeklemesinden faydalanılmıştır. Denemelerimizde CRF algoritması için parametreler; "c1": 1, "c2": 0,001, "maksimum iterasyon": 50 olacak şekilde çalıştırılmıştır. Özellikler sığ olarak (sparse features) temsil edilmiştir.

Kullanılan CRF algoritması, dizilim etiketlemede hangi özelliklerden faydalanılacağını bir şablon olarak kabul etmektedir. Bu şablon üzerinde, incelenmekte olan kelime ve ilişkili olacağı düşünülen kelimelerin (komşu kelimeleri ya da bağlılık ağacında doğrudan bağlantısı olduğu kelimeler) hangi özelliklerinin kullanılacağ verilebilmektedir. Oluşturmuş olduğumuz şablonda kullanılan özelliklerin listesi aşağıdaki gibidir:

Özellik 1: Kelimenin cümle içindeki görünüm hali, Özellik 2: $\quad$ Kelimenin morfolojik çözümlemesinden gelen kökü,

Özellik 3: Kelimenin morfolojik çözümlemesinden gelen POS etiketi.

Özellik 4: $\quad$ Morfolojik çözümleme özellikleri.

Özellik 5: Kelime vektörleri: Türkçe dili için 2 milyar kelime ile oluşturulmuş 200 boyutlu kelime vektörleri [20] kullanılmıştır. Diğer tüm özellikler CRFSuite kütüphanesine nominal gösterim ile eklenirken, kelime vektörleri 200 boyutun ondalık (float) değerlerle temsil edildiği 200 özellik olarak eklenmiştir. Aynı zamanda kelime vektörleri yalnızca incelenmekte olan kelimenin özelliklerinde kullanılmıştır. Kendinden 
önceki veya sonraki kelimelerin özelliklerinde kullanılmamıştır.

Özellik 6: Bağlılık tipi: Kelimenin bağlılık ağacında bağlı olduğu düğümdeki kelime ile olan bağl11ık ilişkisi sisteme özellik olarak verilmiştir.

Etiket ataması için üç farklı yaklaşım (0-1, IOB-Hedef Kategori, Hedef Kategori) denenmiştir. Bu yaklaşımlar için aynı cümle üzerindeki gösterim farklılıkları Tablo 3 'te sunulmuştur. Tabloda üç farklı etiket türü birbirlerinden kesme işareti ile ayrılarak gösterilmektedir: (0-1 / IOBHedef Kategori / Hedef Kategori). İlk yaklaşımda (0-1), bir kelimenin hedef terim olmasına veya hedef terim öbeğinin içinde bulunup bulunmamasına göre 1 veya 0 değerlerini alan etiket bilgisi kullanılmıştır. İkinci yaklaşım (IOBHedef Kategori) için, kelime eğer hedef terim ise, hedef terimin ait olduğu hedef kategori dizilim sinıflandırıcı sisteminde etiket bilgisi olarak kullanılmıştır. Etiket işaretlemeleri yapılırken, isimlendirilmiş varlık tespiti yöntemlerindekine benzer şekilde, eğer mevcut kelime hedef terimin ilk terimi ise (hedef terimin tek kelimeden oluştuğu durumda, o kelime başlangıç olarak kabul edilmektedir) "B-[Hedef Kategori]", eğer ilk terim değil ancak hedef terimin içinde kalan bir kelime ise "I-[Hedef Kategori]" etiketi ile, eğer kelime hedef terimin içinde olan bir kelime değilse " 0 " etiketi ile etiketlenmiştir. Bu gösterim şekline literatürde IOB (Inside, Outside, Beginning) gösterimi adı verilmektedir. Son olarak etiket türüne ham hedef kategorinin konduğu bir senaryo (Hedef Kategori) denenmiştir. Burada kelime hangi hedef kategoriye ait bir terimde bulunuyorsa o kategori ile etiketlenmiştir. Kelimenin o terimin neresinde bulunduğuna dair ayrı bir gösterim kullanılmamaktadır.

Yukarıda belirtildiği üzere, özellik şablonlarında incelenmekte olan kelime ve ilişkili olacağı düşünülen kelimelerin bir diğer deyişle bağlamın hangi özelliklerinin kullanılacağı verilebilmektedir. Bağlamın temsilinde iki farklı yaklaşım denenmiştir. Bunlardan biri pozisyon olarak komşu kelimelerin bağlam olarak kabul edilmesi, bir diğeri ise cümle analizinde (bağlllık ağacında) ilgili kelime ile ilișkili kelimelerin bağlam olarak kabul edilmesidir. Komșuluğun kullanıldığı bağlam gösteriminde $+2-2$ pozisyondaki kelimeler, bağlılığın kullanıldığı bağlam gösteriminde ise $+2-2$ derinlik içerisindeki bağlanan ve bağlanılan kelimeler kullanılmaktadır. Şekil 2'de bir yorum örneği (“Atıştırmalık Jumbo Combo pek lezzetli!”) bağlılık ağacındaki ilişkileri ile birlikte verilmektedir. Hata! Başvuru kaynağı bulunamadı.'de bu örnekteki "Combo" sözcüğünün her iki yöntem ile elde edilen bağlam bilgisi verilmektedir.

Tablo 3. Farklı etiket türleri için CRF eğitim verisi şablonu

\begin{tabular}{|c|c|c|c|c|c|c|}
\hline ID & FORM & LEMMA & $\ldots$ & HEAD & DEPREL & ETIKET (0-1 / IOB-Hedef Kategori / Hedef Kategori) \\
\hline 1 & $\begin{array}{l}\text { Şubelerd } \\
\text { en }\end{array}$ & şube & $\ldots$ & 3 & $\begin{array}{l}\text { MODIFI } \\
\text { ER }\end{array}$ & $0 / 0 / 0$ \\
\hline 2 & en & en & $\ldots$ & 3 & $\begin{array}{l}\text { MODIFI } \\
\text { ER }\end{array}$ & $0 / 0 / 0$ \\
\hline 3 & iyisi & iyi & $\ldots$ & 9 & SUBJECT & $0 / 0 / 0$ \\
\hline 4 & Pendik & Pendik & $\ldots$ & 5 & MWE & 1 / B-RESTAURANT\#GENERAL / RESTAURANT\#GENERAL \\
\hline 5 & merkez & merkez & $\ldots$ & 9 & $\begin{array}{l}\text { MODIFI } \\
\text { ER }\end{array}$ & 1 / I-RESTAURANT\#GENERAL / RESTAURANT\#GENERAL \\
\hline 6 & ana & ana & $\ldots$ & 7 & $\begin{array}{l}\text { MODIFI } \\
\text { ER }\end{array}$ & 1/ I-RESTAURANT\#GENERAL / RESTAURANT\#GENERAL \\
\hline 7 & şubesi & şube & $\ldots$ & 9 & SUBJECT & 1 / I-RESTAURANT\#GENERAL/ RESTAURANT\#GENERAL \\
\hline 9 & iyidir & 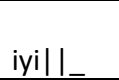 & $\ldots$ & 0 & $\begin{array}{l}\text { PREDIC } \\
\text { ATE }\end{array}$ & $0 / 0 / 0$ \\
\hline
\end{tabular}

(CRF training data template for different types of tags)

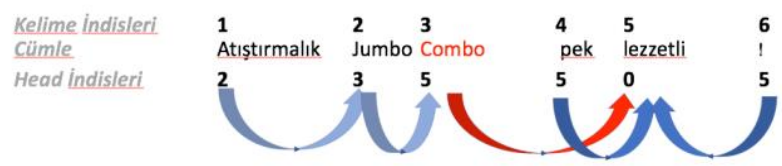

Şekil 2. Örnek bağlılık ağac1

(Dependency links in an example sentence)

\subsection{Hedef Kategori Tespiti (Aspect Category Detection)}

Cümle içerisindeki duygu tanımlama gruplarını üretmek ve bu tanımlama gruplarındaki hedef kategori bilgisinin doldurulmasının hedeflendiği görevde iki farklı ana yöntem çeşitli senaryolarla kurgulanmıştır. İlk yöntem, problemi birçok-sınıflı sınıflandırma (multi-class classification) problemi olarak ele almaktır. Çünkü bir cümle birden fazla ve farklı kategorilerde duygu tanımlama grubu barındırabilmektedir. Uygulanan ikinci yaklaşımda ise bir önceki bölümde tanıtılan dizilim etiketleme yaklaşımı kullanılmaktadır.

Tablo 4. Örnek özellik şablonlarında yer alan kelimeler (The words in different sample feature templates)

\begin{tabular}{|l|l|l|}
\hline İndis & Dizilim & Bağlılık \\
\hline-2 & Atıştırmalık & Atıştırmalık \\
\hline-1 & Jumbo & Jumbo \\
\hline 0 & Combo & Combo \\
\hline 1 & pek & lezzetli \\
\hline 2 & lezzetli & -- \\
\hline
\end{tabular}


Lineer sınıflandırma yaklaşımı ABSA yarışma komitesi tarafından da benimsenen en temel çözüm yaklaşımı olarak ortaya çıkmaktadır. Çalışmamızda ortaya koymak istediğimiz, problemi ele alış biçimindeki farklı yaklaşımlar ile sınıflandırma çözümünün iyi sonuçlar çıkarabileceğinin gösterilmesidir. Çünkü ABSA yarışma komitesi tarafından ortaya konan sınıflandırma çözümü dillere ilişkin doğal dil işleme araçlarının kullanılmadığı, yalnızca eğitim verisinin ham halinin kullanıldığı bir sınıflandırma yaklaşımıdır. Bizim çalışmamızda ise hem doğal dil işleme araçlarından gelecek olan katkının sunulması hem de sınıflandırma probleminde sınıfları ele alış biçimimizdeki farklılık ile sonuçların iyileştirilmesi amaçlanmaktadır. Tanıtılan bu ilk yöntemin dilden bağımsız ön versiyonu ABSA 2016 kapsamında farklı diller için önerdiğimiz çalışmada denenmiştir [21]. Bu sistem ile Hollandaca veri kümesinde en başarılı sonuçlar elde edilmiştir [7]. Bu makalede ise, önerilen yöntem Türkçe'ye uyarlanmış ve sonuçları raporlanmıştır.

Türkçe'de Bölüm 2'de anlatıldığı gibi sınıflandırma çözümlerinde en büyük problem morfolojik zenginliği sebebiyle derlemlerde bir kelimenin çok faklı biçimleriyle karşılaşılmasıdır. Bu özellik sınıflandırma sistemlerinde özellik seyrekliği (feature sparsity) problemine yol açmaktadır. Diğer bir deyişle, problem açısından aynı anlamı taşıyan kelime varyasyonları farklı özellik olarak temsil edilmektedir. Bu problemi aşmak adına Türkçe morfolojik çözümleme ve morfolojik belirsizlik giderme araçları kullanılmış ve kelimeler kökleri ile özelliklerde temsil edilmiştir. Bunun yanı sıra kelime kökleri deneylerde hem tekil (unigram) hem de ikili (bigram) şekilde özelliklerde temsil edilmiştir. Çünkü doğal dilde yazılan metinlerde zaman zaman, kelimelerin sıraları ve birliktelikleri tekil kelimelerin taşıdığı anlamlara ek önemli anlamlar da taşıyabilmektedir. Önerilen ilk yaklaşımımızda, problem çok-sınıflı sınıflandırma (multiclass classification) olarak ele alınmıştır. Bunun sebebi, bir cümlenin birden fazla kategoride duygu tanımlama grubu barındırıyor olabilmesidir. Bunu sağlayabilmek adına, sınıflandırma sisteminde her bir hedef kategori tipi için ayrı ayrı bire-hepsi (one-vs-all) çalışan sınıflandırıcılar eğitilmiştir. Bu tip sınıflandırıcılarda, seçilmiş olan sınıfa ait veriler "1" (pozitif), geriye kalan diğer sınıflara ait veriler "0" (negatif) sınıfi ile işaretlenerek eğitime tabi tutulmaktadır. Bu noktada, negatif örneklerin seçilmesi esnasında, pozitif sınıfa ait duygu tanımlama gurubu barındıran metinler elenmiştir. Anlatmış olduğumuz ana sınıflandırıcı sistemine ek ön işlem sınıflandırıcıları da sistemde başarımı arttırmak için kurgulanmıştır. Bu ön işlem sınıflandırıcılarının görevi, hedef kategoriyi oluşturan hedef varlık ve hedef özellik bileşenlerinin metinde temsil edilme oranlarının bulunmasıdır. Bunun için, her bir hedef varlık ve hedef özellik için ayrı birer sınıflandırıcı yine bire-hep şekilde eğitilmiş ve olasılık sonuçları kullanılmıştır. Ön işleme sınıflandırıcılarının görevi, bir metin için tüm hedef varlık ve hedef özelliklerin temsil oranlarını gösteren olasılıkları üretip ana sınıflandırıcıya birer özellik olarak kazandırmaktır. Hem ön işlem sınıflandırıcılarında hem de ana sınıflandırıcıda sınıflandırma algoritması olarak Logistic Regression seçilmiştir. Sistem tasarımında, algoritmanın gerçeklemelerinden Liblinear [20] kütüphanesi tercih edilmiştir. Sistemin genel mimarisi Şekil 3'te sunulmaktadır.

Dizilim etiketlemeye dayalı önerdiğimiz ikinci hedef kategori bulma yaklaşımı ise, hedef terim bulma bölümünde (5.1) anlatılan yöntemin çıktısının birebir hedef kategori bilgisi olarak kullanılmasına dayanmaktadır. Bölüm 5.1'de anlatıldığı üzere, hedef terim bulmada en yüksek başarımı veren IOB-hedef kategori etiketleme türü doğal olarak çıktısında hedef kategori bilgisini de barındırmaktadır. Bu sayede tek adımda hem hedef terimi hem de hedef kategoriyi tespit eden bir algoritma ortaya çıkmıştır. Bu görevde, önceki görevde elde edilen bu çıktı doğrudan değerlendirmelerde kullanılmıştır.

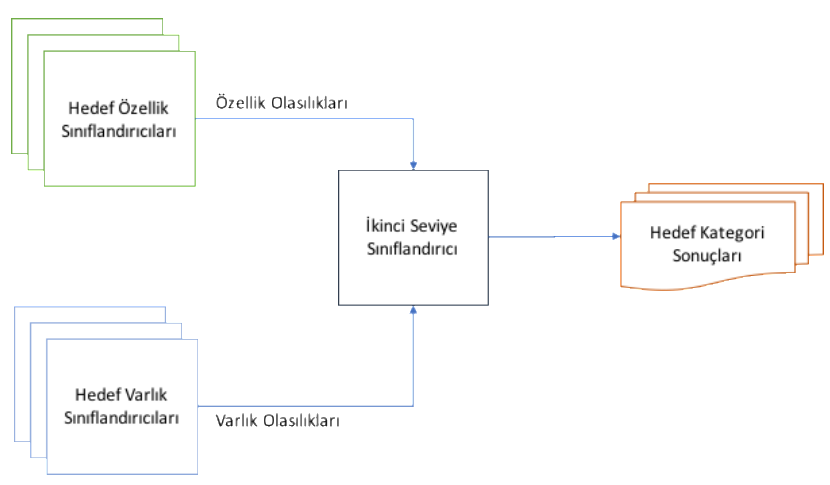

Şekil 3. Hedef kategori tespiti sınıflandırıcı sistemi (The aspect category detection system)

\subsection{Hedef Terim ve Hedef Kategorinin Beraber Bulunmast (Detecting Opinion Target Expression and Aspect Category Synchronously)}

Cümlede bulunan duygu tanımlama gruplarının üretilmesi ve içlerindeki hedef terim ve kategori bilgilerinin doldurulmasının hedeflendiği bu görevde, 5.1 bölümünde anlatılmış olan ve 5.2 bölümünde de kullanılan terimin ait olduğu kategori ile etiketlendiği dizilim etiketleme tekniği kullanılmıştır.

\subsection{Duygu Sinıfinın Bulunmasl (Sentiment Polarity Detection)}

Duygu sınıfları problemin tanıtımında anlatıldığı gibi "pozitif", "negatif", ve "nötr" sınıflarından oluşmaktadır. Görev tanımında cümlelerle birlikte duygu tanımlama grupları da verilmektedir. Duygu tanımlama gruplarında hedef terim ve hedef kategoriler verilmektedir. Verilen duygu tanımlama gruplarında duygu sınıfı bölümleri boş bırakılmıştır. Bu problemin çözümü için, çalıșmamızda lineer sınıflandırma tekniği kullanılmıştır. Sınıflandırıcıda kullanılabilecek özellikler, cümledeki metinlerden gelen metinsel özellikler, duygu tanımlama grubundaki hedef kategori ve yine duygu tanımlama grubundaki hedef terimdir. Sınıflandırıcı olarak Liblinear kütüphanesinden Logistic Regression algoritması kullanılmıştır. Sistem için kullanılan özellikler ise aşağıdaki gibidir: 
- Tüm cümlenin kelimelerinin kökleri ile temsil edildikleri tekil ve 2-gram çantaları,

- Hedef terimin kategorik bilgi olarak temsil edildiği bir özellik gösterimi,

- Hedef varlığın ve hedef özelliğin kategorik bilgi olarak gösterildiği bir özellik gösterimi,

- Hedef terimin $-\mathrm{n}+\mathrm{n}$ penceresinde geçen kelimelerin köklerinin temsil edildikleri kelime tekil çantaları,

- Hedef terimin bağlılık ağacında ilişkili olduğu kelimelerin köklerinin temsil edildikleri tekil kelime çantaları.

\section{DENEYLER (EXPERIMENTS)}

Bu bölümde, Bölüm 5'de anlatılan özellikler ile kurgulanmış deneyler ve sonuçları raporlanmaktadır. Sonuçların kıyaslarının yapılabilmesi adına her bir bölüm için aynı veri kümesi üzerinde daha önce yapılmış çalışmaların sonuçları ve özet olarak içerikleri de yine bu bölümde ele alınmıştır. Literatürde şimdiye dek bu veri kümesi üzerinde sadece hedef kategori çıkarımı (Bölüm 0) ve duygu sınıfı belirleme (Bölüm 6.4) görevleri üzerinde bazı çalışmaların [12, 22-24] sonuçlarının raporlandığ görülmektedir. Diğer görevler için ise çalıştay komitesi tarafından verilen temel sistemler ile karşılaştırmalar sunulmuştur.

\subsection{Hedef Terim Çıkarımı (Opinion Target Expression Extraction)}

Hedef terim çıkarımı için tasarlanan testler, Tablo 5'de kullanılan özellikler üzerinden sunulmaktadır. Test sonuçlarında değerlendirme yapılırken F-1 ölçütü esas alınmıştır. Hedef terimi "NULL" olan duygu tanımlama grupları değerlendirme dışı bırakılmıştır. Tabloda kullanılan özellikler, bağlam temsili ve etiket gösterimi Bölüm 5.1'deki isimlendirmeler ile anılmaktadır. Çalıştayda, bu görev için Türkçe veri kümesinde başka başvuru yapılmadığı için sonuçlar ABSA komitesi tarafindan sunulan temel sistem ile kiyaslanmaktadır. Temel yöntemde izlenen metodoloji sözlük oluşturma tekniğidir. Eğitim verisinde bulunan tüm hedef kategoriler için ayrı sözlükler oluşturulmuş ve bu sözlüklerin içine onları temsil eden eğitim kümesindeki tüm terimler doldurulmuştur. Test ederken hedef kategori tespiti için komite tarafından sunulan temel yöntem kullanılarak cümlelere hedef kategori ataması yapılmaktadır. Bu aşamadan sonra hedef kategori bilindiği için söz konusu hedef kategorinin sözlüğünde bulunan terimlerden, cümle içinde geçenleri hedef terim olarak duygu tanımlama grubunun içine doldurulmuştur. Bir terim eğer aynı cümle içerisinde birden fazla bulunuyorsa, ilki hedef terim olarak belirlenmektedir.

Deneyler sırasında en yüksek başarımlar IOB hedef kategori etiket gösterimi ile elde edilmiştir. Tablo 6'da en iyi model üzerinde farklı etiket türlerinin denendiği test sonuçları sunulmaktadır

Tablo 5. Hedef terim çıkarımı için kurgulanan test senaryoları (Test scenarios for opinion target extraction)

\begin{tabular}{|l|l|l|l|l|}
\hline TEST & ÖZELLIKLER & $\begin{array}{l}\text { BAĞLAM } \\
\text { Temsili }\end{array}$ & $\begin{array}{l}\text { ETİKET } \\
\text { Gösterimi }\end{array}$ & F1 \\
\hline Temel & - & & - & $\% 41.86$ \\
\hline Test 0 & 1 & Komşuluk & IOB & $\% 40.09$ \\
\hline Test 1 & $1+2+3+4$ & Komşuluk & IOB & $\% 47.25$ \\
\hline Test 2 & $1+2+3+4+5$ & Komşuluk & IOB & $\% 48.97$ \\
\hline Test 3 & $1+2+3+4+5+6$ & Bağlılık & IOB & $\% 53.12$ \\
\hline Test 4 & $1+2+3+4+6$ & Bağlılık & IOB & $\% 48.06$ \\
\hline Test 5 & $1+5$ & Komşuluk & IOB & $\% 44.81$ \\
\hline
\end{tabular}

Tablo 6. Etiket türüne göre tüm özelliklerin kullanıldığı test sonuçları

(Test results where all features are used according to label types)

\begin{tabular}{|l|l|}
\hline ETİKET TÜRய̈ & F1 \\
\hline $0-1$ & $\% 51.12$ \\
\hline IOB Hedef Kategori & $\% 53.12$ \\
\hline Hedef Kategori & $\% 51.18$ \\
\hline
\end{tabular}

Önermiş olduğumuz sistem sınırlı bir sistem olduğu için dışarıdan veri kullanılmamıştır. Ancak tartışma bölümünde benzer çalışmalar ile karşılaştırma yapılabilmesi için duygu sözlüklerinden faydalanan bir sistem sürümü de sınanmıştır. Duygu sözlüğü, kelime seçimleri için kullanılmıştır. Bir kelimenin lineer sınıflandırıcıya özellik olarak verilip verilmeyeceğine, duygu sözlüğünde herhangi bir duygu için temsilci olup olmadığı bilgisine bakılarak karar verilmiştir. Bu amaçla kullanılan sözlük (lexicon) NRC Emotion [25] sözlüğünün Türkçe bölümüdür.

\subsection{Hedef Kategori Tespiti (Aspect Category Detection)}

Hedef kategori tespiti için ABSA yarışmasında değerlendirme ölçütü F-1 ölçütüdür. Başvuru yapan diğer ekiplerin, temel sistemin ve çalışmamız kapsamında ortaya koymuş olduğumuz yöntemlerin sonuçları Tablo 7'de sunulmaktadır. ABSA komitesinin bu görev için sunmuş olduğu temel yöntemde Destek Vektör Makinesi (SVM) algoritmasını, lineer çekirdek ile kullanılmıştır. Özellikle, eğitim kümesindeki duygu tanımlama grubuna sahip olan cümlelerden tüm tekil kelimeler çıkarılmıştır. SVM algoritmasında, çıkarılmış olan 1000 adet en sık kullanılan 
kelime özellik olarak alınmıştır. Yarışma komitesi her dil için veri hazırlayan gruplardan; o dilde sık kullanılan ve anlam ifade etmeyen kelime listesi (stopwords) istemiştir. $\mathrm{Bu}$ dilin barındırdığı çok sık geçen kelimeler, özellik seçimi esnasında dışarıda bırakılmıştır. Örneğin, Türkçe için bu kapsama giren "ve","ile","de" vb gibi kelimeler özellik seçiminde kapsam dışı bırakılmıştır. Her bir duygu tanımlama grubu, eğitimde aynı cümlede bile olsalar ayrı ayrı eğitim örneği olarak temsil edilmişlerdir. Bu eğitim örnekleri temsil ettikleri duygu tanımlama gruplarındaki hedef kategori adını kategori bilgisi olarak almışlardır (Ör: "RESTAURANT\#GENERAL"). SVM algoritmas1 olasılıklar üretebilecek şekilde eğitilmiştir. (Komite tarafından kullanılan Libsvm kütüphanesi eğer olasılık üretilmesi gerektiği haricen bildirilmezse bu yeteneğe sahip değildir.) Böylece tahmin yaparken, test örneğinin hangi kategorilere hangi oranlarda ait olabileceği bilgisini almak mümkün olmuştur. Örneğin bir test örneği: RESTAURANT\#GENERAL kategorisini için 0,2 , SERVICE\#GENERAL kategorisini için ise 0,4 oranında temsil ediyor sonucu alınabilmiştir. Bu olasılık değerleri için sistem tamamında geçerli olarak bir eşik değeri komite tarafından belirlenmiş ve bu belirlenen eşik değeri üstünde kalan olasılıktaki kategoriler o test örneğinde bulunmaktadır yorumu yapılmıştır.

Tablo 7. Hedef kategori belirleme test sonuçları (Test results for aspect category detection)

\begin{tabular}{|l|c|}
\hline TEST & F-1 \\
\hline Temel [5] & $\% 58,90$ \\
\hline UFAL [22] & $\% 61,03$ \\
\hline IIT-T [23] & $\% 56,63$ \\
\hline INSIGHT [24] & $\% 49,12$ \\
\hline Çok sınıflı sınıflandırma yaklaşımı [21] & $\% 59,01$ \\
\hline Dizilim etiketleme yaklaşımı & $\% 66,66$ \\
\hline
\end{tabular}

Yarışma kapsamında verilmiş olan en başarılı yöntem olan Ufal [22] ekibinin yönteminde, derin tekrarlayan sinir ağları, sınıflandırıcı olarak kullanılmaktadır. $\mathrm{Bu}$ sinir ağında kelimeler önceden eğitilmiş kelime vektörleri ile kullanılmıştır. Kelime vektörlerini oluşturabilmek için Wikipedia'daki ${ }^{4}$ veriler kullanılmıştır.

Çalışma kapsamında sunmakta olduğumuz asıl yöntemimiz, dizilim etiketleyicilerin bu alt görev için de kullanılmasını önermektedir. Bölüm 6.1'de en başarılı sonuçları üreten; IOB etiket türünü benimseyen, bağlılık ağacındaki ilişkilerin dizilim için kullanıldığı ve kelime vektörlerinden faydalanan sistem bu alt görev için de sınanmıştır.

\subsection{Hedef Terim ve Hedef Kategorinin Beraber Bulunmas (Detecting Both Opinion Target Expression and Aspect Category Detection Together)}

Hedef kategori ve hedef terimin birlikte üretilmesini hedefleyen bu görevde, ölçüm yöntemi önceki görevlerde de olduğu gibi F1 ölçütüdür. Yarışma komitesi tarafindan hazırlanan temel yöntem hedef terim seçme için kullanılan yöntemdeki gibi, cümlenin hedef terim sözlüklerinden hangi terimleri barındırdığını bulmakta ve ardından bu terimlerin geçtiği sözlükleri kategori bilgisi olarak işaretlemektedir. Önermiş olduğumuz sistemin ve yarışma komitesi tarafından verilen temel sistemin başarı oranları Tablo 8'de verilmektedir.

Tablo 8. Hedef terim ve hedef kategorinin beraber bulunma testleri

(Tests for synchronous detection of aspect category and opinion target

\begin{tabular}{|l|l|}
\multicolumn{2}{|c|}{ expression) } \\
\hline TEST & F-1 Ölçümü \\
\hline Temel [5] & $\% 28,15$ \\
\hline Önerilen Sistem & $\% 46,67$ \\
\hline
\end{tabular}

\subsection{Duygu Sinıfinın Belirlenmesi (Sentiment Polarity Detection)}

Yarıșma komitesi tarafından sunulan temel yöntem lineer çekirdekli SVM algoritması ile yapılan bir sınıflandırıcı eğitimine dayanmaktadır. Hedef kategori bulma görevinde gerçekleştirilene benzer şekilde her duygu tipi için en sik geçen tekil kelimeler özellik olarak seçilmiştir. Bunun yanında, işaretli olarak verilen hedef kategori bilgileri, nümerik özellik olarak temsil edilmiştir. Eğer bir cümle farklı duygu tanımlama grupları barındırıyorsa, her bir tanımlama grubu için cümle farklı bir örnek olarak eğitim kümesine alınmıştır. Kategori bilgisi olarak da duygu sınıfları (pozitif, negatif, nötr) kullanılmıştır.

ABSA 2016 başvuruları arasında yer alan en başarılı sınırlı başvuru INSIGHT [24] ekibine aittir. Yapmış oldukları çalışmada, derin öğrenme (Evrişimli nöron ağları - CNN) metodolojisine dayalı bir model ile Türkçe veri kümesinde sonuçlar raporlanmıştır [24]. Bu çalışmada, yazarlar farklı diller için paylaşılan veri kümeleri üzerlerinde eğittikleri dil bağımsız çalışan modellerini sunmuşlardır. Tablo 10 sınırlı sistemler ve önerilen yönteme ait karşılaştırılmaları vermektedir. Yarışmada, duygu sınıfı başarımının değerlendirmesinde doğruluk (accuracy) kullanılmıştır. Tablonun son sütununda genel değerlendirmeye ek olarak ayrica sadece birden fazla duygu tanımlama grubu barındıran cümlelerdeki doğruluk oranları da sunulmuştur. Test kümesindeki tüm hedef kategorilerden duygu sınıfı doğru bulunanların, toplam hedef kategorisi gösteren grupların sayısına bölümü ile hesaplanmaktadır. Duygu sınıflarının bulunabilmesi için tasarlanan test senaryoları aşağıda verilmektedir.

Test 0 . Her bir yorum cümlesinin yalnızca metinsel özelliklerini kullanan (sözcük gövdeleri) bir lineer sinıflandırma sistemidir.

Test 1. Her bir tanımlama grubu veri kümesinde ayrı ayrı temsil edilmektedir. Veri kümesindeki tüm örnekler; "yorum içerisindeki kelimelerin görünüm halleri (surface form)", "duygu tanımlama grubundaki hedef kategori bilgisi", "hedef terim" özellikleri ile gösterilmektedir. Hedef kategori ve hedef terim

\footnotetext{
${ }^{4}$ https://tr.wikipedia.org/wiki/Ana_Sayfa
} 
kategorik bilgi ile temsil edilmektedir. Kelimelerin görünüm hallerinin özellik olarak temsil edilmesinde tekil kelime çantaları yöntemi tercih edilmiştir.

Test 2. Test 1'den farklı olarak her bir kelime görünüm hali ile değil, morfolojik çözümlemeden gelen sözcük gövdeleri ile kullanılmıştır.

Test 3. Test 2'deki ile aynı senaryoda lineer sınıflandırıcı eğitilmiştir. Test cümlelerinde ise yalnızca, metinsel özellik çıkarımında cümledeki tüm sözcükler yerinde, sadece hedef terimin öncesinde ve sonrasında yer alan $\mathrm{n}$ adet komşu sözcük kullanılmıştır. Duygu tanımlama grubunda bulunan hedef kategori kategorik özellik olarak kullanılmıştır. Çeşitli n sayıları test edilmiş ancak en başarılı sonuçları 3 kelime geriden ve 3 kelime ileriden seçilen komşuların olduğu pencerelerde ulaşılmıştır.

Tablo 9. Pencere uzunluğuna göre duygu analizi başarımları

(Sentiment polarity detection success rates by different window sizes)

\begin{tabular}{|l|l|l|l|}
\hline PENCERE UZUNLUĞU & SIRALAMA & BAĞLILIK AĞACI & $\begin{array}{l}\text { SIRALAMA VE BAĞLILIK } \\
\text { AGACI }\end{array}$ \\
\hline 2 & $\% 74,84$ & $\% 72,33$ & $\% 75,47$ \\
\hline 3 & $\% 75,41$ & $\% 72,33$ & $\% 76,10$ \\
\hline 4 & $\% 75,41$ & $\% 72,33$ & $\% 76,10$ \\
\hline 5 & $\% 74,21$ & $\% 72,33$ & $\% 75,47$ \\
\hline 6 & $\% 73,58$ & $\% 72,33$ & $\% 74,84$ \\
\hline
\end{tabular}

Tablo 10. Duygu sınıfı bulma başarısı (Sınırlı dış sistemler ve önerilen sistemler)

\begin{tabular}{|c|c|c|c|}
\hline TEST & Açıklama & $\begin{array}{l}\text { TÜM DUYGU } \\
\text { TANIMLAMA } \\
\text { GRUPLARI } \\
\text { ÜZERINNDE } \\
\text { DOĞRULUK }\end{array}$ & $\begin{array}{ll}\text { BİRDEN FAZLA } & \text { DUYGU } \\
\text { TANIMLAMA } & \text { GRUBU } \\
\text { BARINDIRAN } & \\
\text { CÜMLELERDEKİ } \\
\text { DOĞRULUK }\end{array}$ \\
\hline Temel [5] & & $\% 72.33$ & \\
\hline INSIGHT [24] & & $\% 74,21$ & \\
\hline TEST 0 & Sözcük gövdeleri tekil kelime çantaları & $\% 67,92$ & $\% 77,96$ \\
\hline TEST 1 & $\begin{array}{l}\text { Sözcük görünüm halleri tekil kelime } \\
\text { çantaları }+ \text { hedef terim }+ \text { hedef kategori }\end{array}$ & $\% 65,40$ & $\% 67,79$ \\
\hline TEST 2 & $\begin{array}{l}\text { Sözcük gövdeleri tekil kelime çantaları }+ \\
\text { hedef terim }+ \text { hedef kategori }\end{array}$ & $\% 74,20$ & $\% 84,47$ \\
\hline TEST 3 & TEST $2+-3+3$ kelime penceresi & $\% 75,47$ & $\% 84,47$ \\
\hline TEST 4 & TEST $2+-2+2$ bağlılık ilişkisi penceresi & $\% 72,33$ & $\% 79,66$ \\
\hline TEST 5 & $\begin{aligned} \text { TEST } 2+ & -3+3 \text { kelime penceresi } \\
& +-2+2 \text { bağl1lık ilişkisi penceresi }\end{aligned}$ & $\% 76,10$ & $\% 86,44$ \\
\hline
\end{tabular}

Test 5. Test 3'den tek fark1, yorumlarda seçilen kelimelerin koordinatlarıdır. $\mathrm{Bu}$ testte bağlılık ağacındaki ilişkiler kullanılmaktadır. Hedef terimin bağlılık ağacındaki ilişkili olduğu kelimelerden 2 seviye yukarı ve 2 seviye aşağıya gidilmiştir. Tablo 9'da farklı seviyelerin seçimlerinde ortaya çıkan başarımlar verilmektedir. Buradaki bilgilere bağlılık bilgisinin kullanıldığı testlerde tüm derinlikler aynı sonucu üretmektedir. Daha az kelime sayısı ile aynı başarının yakalandığı 2 seviyeli bağlılık ilişkisi raporlama için seçilmiştir.

Test 6. Bu senaryoda hem bağlılık ağacındaki derinlik hem de terimin komşularından faydalanılmıştır. Diğer bir deyişle Test 3 ve Test 4'de çıkartılan kelimeler birlikte kullanılması tasarlanmıştır. Hedef kategori özelliği önceki testlerdeki gibi kategorik olarak sisteme dahil edilmiştir.

Serbest veri kullanımlı başvurular arasında en başarılı sonuç IIT-T [23] ekibine aittir. Duygu sözlüklerinden (lexicon) faydalandıkları bir çalışmayı sunmuşlardır. Yaptıkları çalışmada SentiTurkNet [26] ve NRC Emotion [27] çalışmasındaki Türkçe sözlüğünden faydalanmışlardır. Yazarlar bu çalışmada söz konusu sözlükleri başlangıç verisi olarak kullanmış, görülmeyen örnekleri de sisteme dahil edebilmek için sözlüklerini genişletme yoluna gitmişlerdir. Bu sözlükler kelimelerin pozitif, negatif ve nötr sınıfları üzerindeki puanlarını barındırmaktadırlar. $\mathrm{Bu}$ puanları kullanarak, verilen örnekteki toplam negatif, pozitif ve nötr puanları hesaplanmış ve özellik olarak sınıflandırıcı sisteminde kullanılmıştır. Bununla beraber örneklerdeki tüm tekil ve ikili kelime birliktelikleri çıkarılmış bunlar da varlık ve yokluk temsili üzerine özelliklerde temsil edilmiştir. Örnek bu özelliklerden barındırdıkları için 1, barındırmadıkları için 0 değerini vermiştir. Yine hedef kategoride ikili bir özellik olarak sisteme dahil edilmiştir. IIT ekibi bu çalışması ile \%84.28'lik bir başarı yakalamıştır.

ABSA 2016 Türkçe veri kümesinde raporlanan diğer bir çalışma Dehkharghani’nin [12] yapmış olduğu yayında 
sunulmaktadır. Ancak bu çalışma test verisi üzerinde değil eğitim verisi üzerinde sınanmıștır. $\mathrm{Bu}$ sebeple diğer çalışmalar ile doğrudan kıyaslama doğru olmayabilir. Yayında söz konusu olan çalışma sözlük tabanlı bir duygu analizi çalışmasıdır ve yazarlar çalışmalarında, hedef tabanlı duygu analizi için hedef terimde yer alan kelimelerin bağlılık ağacındaki baş düğümlerini incelemişlerdir. Sistem olarak serbest bir sistem olan bu çalışmanın başarımı \%68,31'dir.

\subsection{Tartışmalar (Discussions)}

Önceki kısımlarda ortaya konan deneyler ve sonuçlara göre, araştırmadaki en büyük başarı katkılarının hedef terim ve hedef kategori bulmada gösterildiğini söylemek yanlış olmayacaktır. Hedef terim belirleme için önerilen dizilim etiketleme sisteminin, hedef kategori bulmada da oldukça başarılı olduğu bu makalede gösterilmiştir. Dizilim etiketleme sistemlerinde kullandığımız özellikleri irdelemek gerekirse; hedef terimi çıkarımında (Tablo 5) bağlılık bilgilerinin kullanıldığı test senaryosunun (Test 3), kullanılmadıkları senaryoya (Test 2) oranla 4.15 yüzde puanı daha başarılı sonuç verdiği görülmektedir. Aynı kıyas hedef kategori tespitinde yapıldığında 3 puanlık, hem kategori hem terimin doğru bulunmasını amaçlayan üçüncü görevde ise 4,7 puanlık bir fark gözlemlenmektedir. Türkçe gibi serbest dizilimli dillerde, cümle içindeki kelimelerin dizilimi, semantik olarak her zaman doğru birliktelikleri göstermemektedir. Bunun yerine kelimeler arası ilişkilerin tutulduğu bağlılık bilgileri, kelimelerin birliktelikleri açısından daha fazla bilgi sunmaktadırlar.

Hedef terim çıkarımı için doğal dil işleme araçlarının katkıları sonuçlar üzerinden irdelenecek olursa; Tablo 5'ya göre, kelimelerin yalnızca görünüm hallerindeki bilgilerden faydalanılarak oluşturulan dizilim etiketleme sisteminin (Test 0 ) hedef terim bulmada vermiş olduğu başarı \%40,09 iken morfolojik çözümlemeden gelen bilgilerin kullanıldığ yöntemde (Test 1) bu başarı \%47,25 değerine yükselmektedir. Yalnızca morfolojik çözümlemeden gelen bilgilerin katkısı yaklaşık 7 puandır. Morfolojik bilgilerin üstüne kelime vektörlerinin dahil edilmesinin (Test 2) başarıya katkısı yaklaşık 1,5 puandır. Yine morfolojik çözümleme bilgilerinin üzerine yalnızca bağlılık çözümleme bilgileri eklendiğinde (Test 4) yaklaşık 1 puanlık bir artış ortaya çıkmaktadır. Şaşırtıcı şekilde hem kelime vektörlerinin hem de bağlilık çözümleme bilgilerinin birlikte kullanımının katkısı yaklaşık 5.9 puandır. (Test 1 - Test 3) Oysa bu iki bilginin bağımsız olarak eklendiği test senaryolarındaki (Test 2 ve Test 4) katkılar bu orana göre oldukça düşüktür. $\mathrm{Bu}$ da göstermektedir ki, kelime vektörlerinin bağlılık çözümleme bilgisi ile birlikte kullanılması hedef terim çıkarımı için tasarlanan dizilim etiketleme probleminde büyük oranda katkı sağlamaktadır. Dile özgü doğal dil işleme araçlarının ve kelime vektörlerinin kullanılması temel sisteme göre 13 puan (Test 0 - Test 3) gibi yüksek bir oranda başarı getirmektedir.

Kelime vektörleri son zamanlarda kendine oldukça sık kullanım alanı bulan dile özgü kaynaklar arasında yer almaktadır. Çalışmamızda, kelime vektörlerinin Türkçe hedef tabanlı duygu analizi görevlerine de katkı sağladığ gösterilmiştir. Özellikle hedef terim çıkarımında 5,06 puanlık (\%48,06 - \%53,12) (Test 4 - Test 3) bir katk1 sağladığı görülmektedir. Ancak elde edilen artışlar İngilizceye kiyasla halen daha geri seviyelerdedir. Türkçede sondan eklemeliliğin getirdiği veri seyrekliği problemi İngilizce dilinde bulunmamaktadır. Ayrıca kullanılan derlem boyutları da halen İngilizcenin gerisinde kalmaktadır. Çalışmamız kapsamında kullanmış olduğumuz kelime vektörlerinde kullanılan derlemde kelimeler, metinlerde geçtikleri gibi (surface form) eğitildiği için, bir kelimenin eş anlamlılarına yakınlığından çok, farklı morfolojik özelliklerle geçen hallerine yakınlığı puanlanmış durumdadır. Kelimelerin kökleri ve farklı biçimbilimsel temsil gösterimleri ile eğitilmiş kelime vektörlerinin probleme etkilerinin gelecek çalışmalarda irdelenmesinin önemli olduğu değerlendirilmektedir.

Dizilim etiketleme için seçilen etiket türlerine dair sonuçlar incelendiğinde (Tablo 6); IOB formatında etiket türlerinin kullanılması en yüksek başarımı getirdiği gözlemlenmektedir. Yalnızca hedef kategorinin etiket olarak kullanıldığı ve ["1", " 0 "] etiket değerlerinin seçildiği senaryolardaki başarımlar ise büyük oranda aynı sonucu üretmektedir. Düzgün yazılı metinlerde isimlendirilmiş varlık tespiti görevi için ham etiket türlerinin kullanımının IOB formatından daha başarılı olduğu yapılmış olan bir çalışmada [28] sunulmuştur. Ancak bu çıkarım, bizim veri kümemizde ve görevimizde farklı çıkmıştır. Bu farklılığın, kullanılan yazım dillerinden kaynaklandığı düşünülmektedir. Düzgün yazılı metinlerde, aynı türdeki etiketleri barındıran varlıklar, birbirlerinden belirli birimler ile ayrılarak (örneğin noktalama işaretleri, bağlaçlar vb.) yazılmaktadır. Bizim veri kümemiz ise, internet üzerinden toplanmış kullanıcı yorumlarını barındırmaktadır ve yazım yanlışları barındırmaktadır. Veri kümemizde, özellikle noktalama işaretlemeleri yönünden oldukça noksan örnekler mevcuttur. $\mathrm{Bu}$ örneklerden bir tanesi Şekil 4 'te verilmektedir. Örnekte art arda gelen iki farklı terim arasında herhangi bir noktalama işareti veya bağlaç kullanılmamıştır. 


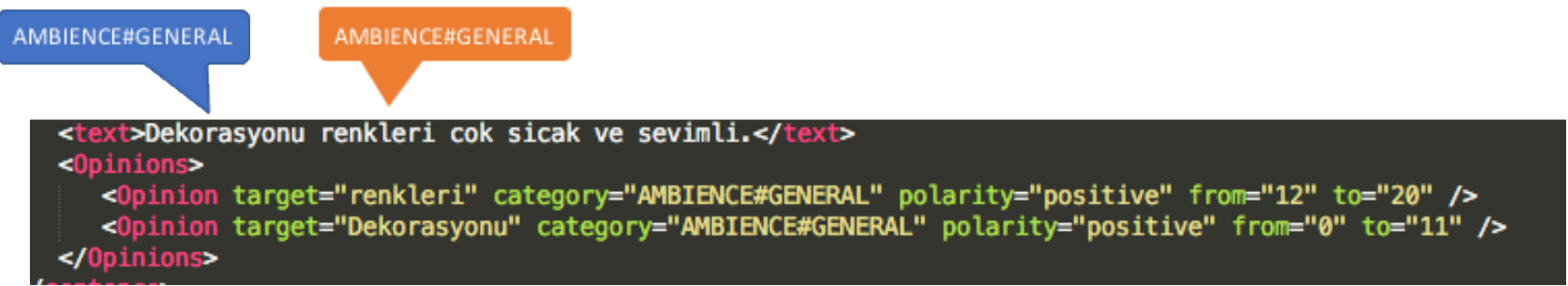

Şekil 4 Aynı tip etiketlerin bitişik yazıldığı bir cümle örneği

(Example sentence where same categories exist side by side)

Yapılabilecek diğer bir çıkarım, hedef terim çıkarma gibi bir probleme, sözlük vb. yaklaşımlar yerine dizilim etiketleme çözümünün katkısının oldukça büyük olduğudur. En başarılı dizilim etiketleme yöntemi (Tablo 5 Test 3) ile temel yöntem (Temel) arasındaki fark 11,26'dır $(\% 41,86-\% 53,12)$.

Hedef terimin tespitinin, hedef tabanlı duygu analizi için önem taşıdı ğ yapılan testler ile ortaya konmuştur. Hedef kategori tespiti gibi ilk bakışta oldukça net bir sinıflandırma problemi gibi duran problemin bile çözümünde hedef terimleri doğru seçebilen bir sistem, sınıflandırma sistemlerinden çok daha başarılı olabilmiştir. $\mathrm{Bu}$ yöntem lineer sınıflandırma tekniğinden yaklaşık 7,6 puan, derin öğrenme yöntemi ile sinıflandırma yönteminden ise 5,6 puan daha başarılı gözükmektedir. Hedef kategori tespiti için önermiş olduğumuz sistem, hedef terim olarak "NULL" değerlerini barındıran (bir diğer deyişler hedef terim içermeyen) duygu tanımlama gruplarını bulma yetisine sahip değildir. Kullanmış olduğumuz test kümesinde bu tip verilerle karşılaşmadığımız için bu eksiklik problem oluşturmamıştır. Ancak söz konusu örneklere sahip test kümelerinde karşılaşılabilecek problemleri aşmak için, önermiş olduğumuz dizilim etiketleme yaklaşımının, çok sınıflı sınıflandırma yaklaşımı ile birlikte kurgulandığı hibrit bir sistem gelecek çalışmalarda tasarlanabilir.

Üçüncü görev olan hedef terim ve hedef kategorinin beraber tespitinin yapıldığı bölümde ortaya çıkarmış olduğumuz başarı (Tablo 8) ABSA yarışmasındaki diğer dillerdeki başvuruların başarılarını yakalamış durumdadır [5]. Bu görev diğer tüm diller içinde en zor görev olarak ortaya çıkmaktadır. Bizim önermiş olduğumuz yöntemin vermiş olduğu başarının, eksik görmüş olduğumuz ve bu bölümde vurguladığımız çalışmaların katkısı ile daha da yukarılara çekilebileceği beklentilerimiz arasındadır.

Hedef terim ve kategori ile ilgili duygu sınıfının bulunması görevinde, ortaya koymuş olduğumuz sistem, herhangi bir dış veriden faydalanmayan, yalnızca eğitim verisindeki bilgilerden çıkarımlar yapan bir sınıflandırma sistemi olmuştur. Burada elde etmiş olduğumuz başarım $(\% 76,10)$ ile ABSA'da verilmiş olan en başarılı sınırlı sistem başvurusundaki (INSIGHT [24]) sonuçtan daha başarılı bir sonuçtur. INSIGHT [24] takımı yapmış olduğu çalışmada derin öğrenme yöntemlerini kullanmış ve bizim raporladığımızdan daha düşük bir başarım ortaya koymuştur. Bizim sistemimiz klasik lineer sınıflandırıcı çözümleri ile çalışan bir yaklaşıma dayanmaktadır. Bu sebeple, son günlerde çok gündemde olan derin öğrenme çalışmalarının, kısıtlı veri ile ortaya koyduğu başarımların duygu analizi problemi özelinde lineer sinıflandırıcı çözümlerinden daha başarılı olduğunu söylemek mümkün değildir. Aynı bölümde başvuru yapan başka bir çalışma olan IIT [23]serbest bir sistem ile yarışmaya katılmış ve \%82,28 başarı oranı raporlamıştır. IIT ekibinin çalışması da derin öğrenme metodolojilerini kullanmaktadır. Ancak onlar derin öğrenme sistemlerine dışarıdan almış oldukları duygu sözlüklerini ve derlemleri dahil etmişlerdir.

Dehkharghani'nin [12] çalışması ile doğrudan kıyaslama imkanımız olmasa da, o çalışmanın Restoran veri kümesindeki sonuçları oran olarak karşılaştırıldığında, sözlük kullanmayan sistemimizin bile oldukça farkla yüksek başarım verdiği görülebilmektedir (\%68,3 $\% 76,10)$.

Duygu sınıflandırma için, hedef terim ile ilgili kesitin bulunması amaciyla yapmış olduğumuz farklı uzunluklardaki ve farklı iki yaklaşımla oluşturulan testlerimizde ortaya çıkan sonuçlar incelendiğinde, kelimelerin sıralamasının kullanıldığı yaklaşımın oldukça küçük bir pencere uzunluğunda (3) en yüksek başarıyı $(\% 75,41)$ getirdiği gözlemlenmiştir. Yalnızca bağlılık ilişkisinin kullanıldığ artış gösterememiş olsa da, hem komşuluğun hem de bağlılığın aynı anda kullanıldığı testlerin en başarılı sonuçları $(\% 76,10)$ ortaya koyduğu gözlemlenmektedir. Kelime komşuluğunun, serbest dizilimli olan Türkçe dilinde tüm örnekler için en uygun kesiti ortaya çıkaramadığı, eksik kalan örneklerin ise bağlılık ilişkisi ile yakalanabildiğinin söylenmesi yanlış olmayacaktır.

Duygu sınıfını belirlemede, özellikle birden fazla duygu tanımlama grubu barındıran cümlelerdeki başarı oranlarını değerlendirmek için Tablo 10'da başarı değerleri sunulmuştur. Test 3 yalnızca hedef terimin etrafindaki kelimeleri değerlendiren bir yaklaşım olmasına rağmen, Test 2 ile aynı oranda başarı göstermektedir. Bu yaklaşımın umulanın aksine birden fazla duygu tanımlama grubu barındıran cümlelerde başarım artışı sağlamadığı gözlemlenmektedir. Yalnızca bağlılığa göre hedef terim ile ilişkili olan kelimelerin kullanıldığı Test 4 ise daha düşük bir başarı oranı göstermektedir. Ancak en yüksek başarıyı bütün cümlelerde olduğu gibi, birden fazla duygu tanımlama grubu barındıran cümlelerde de hem kelime komşuluğunun hem de bağlılık ilişkilerinin kullanıldığ senaryo (Test 5) yakalamıştır. Bu da göstermektedir ki, hedef terimin ilişkili kelimelerini bulmada başarılı olan bu sistem farklı duygu tanımlama gruplarına sahip 
cümlelerde, duygu tanımlama gruplarını birbirinden ayırmada da başarılıdır.

\section{SONUÇLAR VE GELECEK ÇALIŞMALAR (CONCLUSION AND FUTURE WORKS)}

$\mathrm{Bu}$ makalede, Türkçe hedef tabanlı duygu analizi konusunda yapılan incelemelerimiz sunulmuştur. Yürütülen çalışmalar, ABSA 2016 yarışmasındaki görevler (1- Hedef kategori belirleme, 2- Hedef terim belirleme, 3- Hedef kategori ve hedef terimin aynı anda belirlenmesi ve 4- Duygu sınıfi belirleme) takip edilerek tasarlanmış ve yine burada sağlanan Türkçe restoran yorumları veri kümesi üzerinde değerlendirilmişlerdir. Hedef kategori, hedef terim ve ikisinin aynı anda belirlenmesi görevleri için, kelime vektörleri (word vectors) ve doğal dil işleme çıtıları (sözcük ve cümle analizi bilgileri) kullanan koşullu rastgele alanlara (CRF conditional random fields) dayalı bir dizilim etiketleme algoritması tasarlanmış ve her üç görevi de tek aşamada çözebildiği gösterilmiştir. Elde edilen sonuçlar ile bu ilk üç görev için literatürdeki en yüksek başarımların elde edildiği görülmüştür: Hedef kategori belirlemede $\% 66,7$ F1-skoru, hedef terim belirleme \%53,2 F1-skoru, hedef kategori ve hedef terimin aynı anda belirlenmesinde \% 46,7 F1-skoru. Bunun yanı sıra, duygu sınıfi belirleme için cümle analizi sonucunda hedef terime yakın kelimelerden özellik seçimine dayalı bir lineer sınıflandırma yöntemi sunulmuş ve literatürde sınırlı sistemler tarafından raporlanan en başarılı sonuç (\%76,1 F1-skoru) elde edilmiştir.

Makalede, Türkçe hedef tabanlı duygu analizi çalışmalarında, hedef terim ve hedef kategori bulma görevlerinde, kelime vektörlerinin pozitif etkileri ve Türkçe'nin serbest dizilimli yapısı sebebiyle ortaya çıkan problemleri aşmak amacı ile tüm alt görevlerde bağlılık ayrıştırıcı kullanmanın faydaları ortaya çıkarılmıştır. Gelecek çalışmalar için morfolojik bilgilerden faydalanılan farklı kelime vektör yaklaşımları üzerine yapılacak çalışmaların başarımları arttıracağı düşünülmektedir. Takiben, derin öğrenme yöntemlerine dayalı serbest sistemlerin bitişken diller üzerinde başarılı şekilde nasıl kullanılabileceğine dair incelemeler yapmak araştırmacıların önünde yeni bir araştırma konusu olarak bulunmaktadir.

\section{KAYNAKLAR (REFERENCES)}

[1] Pang, B. and L. Lee, Opinion mining and sentiment analysis. Foundations and Trends $®$ in Information Retrieval, 2008. 2(1-2): p. 1 135 .

[2] Liu, B., Sentiment analysis and opinion mining. Synthesis lectures on human language technologies, 2012. 5(1): p. 1-167.

[3] Pang, B. and L. Lee. A sentimental education: Sentiment analysis using subjectivity summarization based on minimum cuts. in Proceedings of the 42nd Meeting of the Association for Computational Linguistics (ACL'04), Main Volume, Barcelona, Spain. 2004. Association for Computational Linguistics.
[4] Wilson, T., J. Wiebe, and P. Hoffmann. Recognizing contextual polarity in phrase-level sentiment analysis. in Proceedings of the conference on human language technology and empirical methods in natural language processing. 2005. Vancouver, British Columbia, Canada: Association for Computational Linguistics.

[5] Pontiki, M., D. Galanis, H. Papageorgiou, I. Androutsopoulos, S. Manandhar, A.-S. Mohammad, M. Al-Ayyoub, Y. Zhao, B. Qin, O. De Clercq, V. Hoste, M. Apidianaki, X. Tannier, N. Loukachevitch, E. Kotelnikov, N. Bel, S.M. Jimenez-Zafra, and G. Eryiğit, SemEval-2016 Task 5: Aspect Based Sentiment Analysis. Proceedings of the 10th International Workshop on Semantic Evaluation, SemEval '16, San Diego, California, June 16-17, 2016, 2016: p. 19-30.

[6] Pontiki, M., D. Galanis, H. Papageorgiou, S. Manandhar, and I Androutsopoulos, SemEval-2015 Task 12: Aspect Based Sentiment Analysis. Proceedings of the 9th International Workshop on Semantic Evaluation (SemEval 2015), Denver, Colorado, 2015: p. 486-495.

[7] Pontiki, M., D. Galanis, J. Pavlopoulos, H. Papageorgiou, I. Androutsopoulos, and S. Manandhar, Semeval-2014 task 4: Aspect based sentiment analysis. Proceedings of SemEval, 2014: p. 27-35.

[8] Torunoglu, D. and G. Eryigit. A cascaded approach for social media text normalization of Turkish. in Proceedings of the 5th Workshop on Language Analysis for Social Media (LASM)@ EACL. 2014. Gothenburg, Sweden: Association for Computational Linguistics.

[9] Eryiğit, G. and D. Torunoğlu-Selamet, Social Media Text Normalization for Turkish. Natural Language Engineering, 2017(Accepted for publication).

[10] Kaya, M., G. Fidan, and I.H. Toroslu. Sentiment analysis of turkish political news. in Proceedings of the The 2012 IEEE/WIC/ACM International Joint Conferences on Web Intelligence and Intelligent Agent Technology-Volume 01. 2012. Macau, China: IEEE Computer Society.

[11] Yıldırım, E., F.S. Çetin, G. Eryiğit, and T. Temel, The impact of NLP on Turkish sentiment analysis. TÜRKIYE BILISSIM VAKFI BİLGISAYAR BİLIMLERİ ve MÜHENDİSLİĞİ DERGİSİ, 2015. 7(1 (Basil1 8).

[12] Dehkharghani, R., B. YANIKOGLU, Y. SAYGIN, and K. Oflazer, Sentiment analysis in Turkish at different granularity levels. Natural Language Engineering, 2016: p. 1-25.

[13] Eryiğit, G., J. Nivre, and K. Oflazer, Dependency parsing of Turkish. Computational Linguistics, 2008. 34(3): p. 357-389.

\section{[14] Eryigit, G. ITU Turkish NLP Web Service. in EACL. 2014.}

[15] Buchholz, S. and E. Marsi. CoNLL-X shared task on multilingual dependency parsing. in Proceedings of the Tenth Conference on Computational Natural Language Learning. 2006. New York City, New York: Association for Computational Linguistics.

[16] Lafferty, J., A. McCallum, and F. Pereira. Conditional random fields: Probabilistic models for segmenting and labeling sequence data. in Proceedings of the eighteenth international conference on machine learning, ICML. 2001. San Francisco, CA, USA: Morgan Kaufmann Publishers Inc.

[17] Alghunaim, A., A Vector Space Approach for Aspect-Based Sentiment Analysis. 2015, Massachusetts Institute of Technology.

[18] Toh, Z. and J. Su, NLANGP at SemEval-2016 Task 5: Improving Aspect Based Sentiment Analysis using Neural Network Features. Proceedings of the 10th International Workshop on Semantic Evaluation, SemEval '16, San Diego, California, June 16-17, 2016, 2016: p. 282-288.

[19] Okazaki, N., CRFsuite: a fast implementation of conditional random fields (CRFs). 2007. 
[20] Şahin, G.G. Turkish Word Embeddings. 2016; Available from: http://isguderg.ml/embedding.html.

[21] Çetin, F.S., E. Yıldırım, C. Özbey, and G. Eryiğit, TGB at SemEval-2016 Task 5: Multi-Lingual Constraint System for As-pect Based Sentiment Analysis. Proceedings of SemEval, 2016: p. 337-341.

[22] Tamchyna, A. and K. Veselovská, UFAL at SemEval-2016 Task 5: Recurrent Neural Networks for Sentence Classification. Proceedings of the 10th International Workshop on Semantic Evaluation, SemEval '16, San Diego, California, June 16-17, 2016, 2016: p. 367-371.

[23] Kumar, A., S. Kohail, A. Kumar, A. Ekbal, and C. Biemann, IIT TUDA at SemEval-2016 Task 5: Beyond Sentiment Lexicon: Combining Domain Dependency and Distributional Semantics Features for Aspect Based Sentiment Analysis. Proceedings of the 10th International Workshop on Semantic Evaluation, SemEval '16, San Diego, California, June 16-17, 2016, 2016: p. 1129-1135.
[24] Ruder, S., P. Ghaffari, and J.G. Breslin, INSIGHT-1 at SemEval2016 Task 5: Deep Learning for Multilingual Aspect-based Sentiment Analysis. Proceedings of the 10th International Workshop on Semantic Evaluation, SemEval '16, San Diego, California, June 16-17, 2016, 2016.

[25] Mohammad, S.M. and P.D. Turney, Nrc emotion lexicon. 2013, NRC Technical Report.

[26] Dehkharghani, R., Y. Saygin, B. Yanikoglu, and K. Oflazer, SentiTurkNet: a Turkish polarity lexicon for sentiment analysis. Language Resources and Evaluation, 2016. 50(3): p. 667-685.

[27] Mohammad, S. NRC Word-Emotion Association Lexicon. 2013 Available from: http://saifmohammad.com/WebPages/NRC-EmotionLexicon.htm.

[28] Şeker, G.A. and G. Eryiğit, Extending a CRF-based named entity recognition model for Turkish well formed text and user generated content. Semantic Web Journal, 2017(doi:10.3233/SW-170253). 